\title{
DEVELOPMENT STRATEGIES OF UBUD VILLAGE AS A CULTURAL M.I.C.E. (MEETING, INCENTIVES, CONVENTIONS, EXHIBITIONS) DESTINATION IN BALI
}

\author{
I GPB Sasrawan Mananda ${ }^{1}$, Luh Gede Leli Kusuma Dewi ${ }^{2}$ \\ ${ }^{1}$ Email: gusmananda@unud.ac.id \\ Program Studi S1 Industri Perjalanan Wisata, Fakultas Pariwisata, Universitas Udayana \\ ${ }^{2}$ Email: leli.kusumadewi@gmail.com \\ Program Studi S1 Industri Perjalanan Wisata, Fakultas Pariwisata, Universitas Udayana
}

\begin{abstract}
Abstrak: The concept of mass tourism has two seasons namely high season and low season to determine the number of tourist visits each year, therefore the tourism industry to try to conduct a vigorous promotion by carrying out activities that can bring tourists to stay in one tourist destination. One of the activities that entrepreneurs do in the low season is to conduct activities M.I.C.E. (Meetings, Incentives, Conventions and Exhibitions). This research uses descriptive qualitative analysis technique by applying the participatory principle involving M.I.C.E stakeholders, destination manager, travel agent managers and tourists. Ubud Village as a tourist destination also has potential for M.I.C.E activities has not had a convention bureau, this is due to the characteristics of the tourists who come to Ubud and the needs required by the tourism industry managers are different from other tourist destinations in Bali such as Badung regency and Denpasar municipality. During this time, the implementation activities of M.I.C.E. dominated by incentives tourism activities (56.57\%), exhibitions $(31.72 \%)$ and meetings $(11.71 \%)$. The SWOT results concluded that Ubud Village is still $\mathrm{S}>\mathrm{W}$ and $\mathrm{O} \geq \mathrm{T}$ thus requiring internal consolidation, but seeing $\mathrm{O} \geq \mathrm{T}$ has potential for further development. Development strategy were using grand strategy which make the results such as growth, dominance, and maximum investment.
\end{abstract}

Keywords: M.I.C.E Strategy, Marketing

\section{PRELIMINARY}

The concept of mass tourism has two seasons of high season and low season which determines the number of tourist visits each year. There are two high season in the month of July-August and December-January while the other months are low season. This causes the tourism industry to promote an intense promotion and activities that can bring tourists to stay or enjoy the tourist destinations of the season. One of the activities that entrepreneurs do in the low season is to conduct activities M.I.C.E. (Meetings, Incentives, Conventions and Exhibitions) that is very useful to bring in the number of continuous tourists to Indonesia in general and Bali in particular.

In terms of handling convention activities, Bali has a good reputation to compete and seize the opportunity in proceeding international and national M.I.C.E. By 2015 almost half of the total activities of M.I.C.E. throughout Indonesia is implemented in Bali. A total of 118 activities have been held in Bali, where there has been an increase in 2013 and 2014. The development of business activities of M.I.C.E. conducted by the hotel is shown by Table 1 below:
Table 1

The Number of National and International Conventions in Bali from 2013 until 2015

\begin{tabular}{crlrrrr}
\hline CONVENTION & \multicolumn{7}{c}{ YEAR } \\
\cline { 2 - 7 } FASILITIES & $\mathbf{2 0 1 3}$ & $+/-\%$ & $\mathbf{2 0 1 4}$ & \multicolumn{1}{c}{$\%$ \% } & $\mathbf{2 0 1 5}$ & \multicolumn{1}{c}{$+/-\%$} \\
\hline Type of Convention: & 83 & $(34.65)$ & 106 & 27.71 & 118 & 11.32 \\
\hline A. National & 7 & $(69.57)$ & 32 & 357.14 & 33 & 3.13 \\
\hline B. International & 76 & $(26.92)$ & 74 & $(2.63)$ & 85 & 14.86 \\
\hline Number of Participant & 10,000 & $(50.00)$ & 75.333 & 653.33 & 10,000 & $(86.73)$ \\
\hline Type of Activity: & 83 & $(34.65)$ & 106 & 27.71 & 118 & 11.32 \\
\hline A. Meeting & 45 & $(40.00)$ & 33 & $(26.67)$ & 79 & 139.39 \\
\hline B. Incentive & 2 & & 8 & 300.00 & 1 & $(87.50)$ \\
\hline C. Convention & 30 & $(40.00)$ & 44 & 46.67 & 35 & $(20.45)$ \\
\hline D. Exhibition & 6 & 200.00 & 21 & 250.00 & 3 & $(85.71)$ \\
\hline
\end{tabular}

Data source: Bali Goverment Tourism Office (2016)

As for the data collection of the business development activities for convention services, 15 hotels in Bali are diligently deposited reports of convention activities, the number of foreign and domestics tourists with purpose of visit o M.I.C.E. activities can be seen in Table 2 below: 
Table 2

The Number of Foreign and Domestic Tourists to Bali from 2008 until 2015

\begin{tabular}{|c|c|c|c|c|c|c|c|c|}
\hline \multirow[b]{2}{*}{ ar } & \multicolumn{2}{|c|}{ Percentage } & \multicolumn{2}{|c|}{ Number of Tourist } & \multicolumn{2}{|c|}{ M.I.C.E Tourist } & \multirow[b]{2}{*}{ TOTAL } & \multirow[b]{2}{*}{$+1 . \%$} \\
\hline & $\begin{array}{l}\text { Forign } \\
\text { Tourist }\end{array}$ & $\begin{array}{c}\text { Domestic } \\
\text { Tourist }\end{array}$ & $\begin{array}{l}\text { Foreign } \\
\text { Tourist }\end{array}$ & $\begin{array}{l}\text { Domestic } \\
\text { Tourist }\end{array}$ & $\begin{array}{l}\text { Foreign } \\
\text { Tourist }\end{array}$ & $\begin{array}{c}\text { Domestic } \\
\text { Tourist }\end{array}$ & & \\
\hline 08 & $3.63 \%$ & & $1,968,892$ & $2,898,794$ & 71,471 & 115,952 & $18 T_{0}$ & \\
\hline 99 & $3 \%$ & & 45 & 3,5 & 80,947 & & 126,722 & 2L. \\
\hline 10 & $1.91 \%$ & & $2,493,058$ & 4,646 & 47,617 & 190,500 & 238,117 & 87. \\
\hline & $3.25 \%$ & & $2,756,579$ & 5,675 & 89,589 & 51 & 146,340 & $(38.5$ \\
\hline 12 & $2.10 \%$ & & $2,892,019$ & $6,063,558$ & 60,732 & 5,305 & 376,037 & 156.9 \\
\hline & $3.55 \%$ & & $3,278,598$ & $6,979,535$ & 116,390 & 251,263 & 367,653 & $(2.23$ \\
\hline & $6 \%$ & $0 \%$ & $3,766,638$ & $6,392,461$ & 164,225 & 460,257 & 624,483 & 69.86 \\
\hline (1) & $36 \%$ & $2.40 \%$ & $4,001,835$ & $7,147,100$ & 174,480 & 171,530 & 346,010 & $(44.5)$ \\
\hline
\end{tabular}

Data source: Bali Goverment Tourism Office (2016)

Bali Provincial Regulation No. 2 of 2012 states that the development of tourism in Bali in accordance with the concept of cultural tourism, so that Bali culture needs to be maintained in order to stay continously and sustainable. One of the tourist destination that keeps its culture is Ubud Village which still maintains Balinese culture and also as an international village which is able to attract tourists to come visit to Ubud. The village of Ubud is divided into 8 villages: Kedewatan, Lodtunduh, Mas, Peliatan, Petulu, Sayan, Singakerta and Ubud Village.

Based on the above-mentioned background, the specific objectives of this research are:

1. Identify elements of M.I.C.E. products in Ubud Village.

2. Identify cultural product of M.I.C.E.using marketing mix aspect (4P).

3. Designing product development strategy of Ubud Village as M.I.C.E. destination

\section{LITERATURE REVIEW}

\section{A. Tourism Definitions}

Herman V. Schulard (1910) provide restrictions on tourism definition as follows: Tourism is the sum of operations, mainly of an economic nature, which the directly to the entry, stay and movement of foreigner in said of country, city or region.

More technical limits are provided by Prof. Hunzieker and Prof. K. Krapf such as: Tourism is the totally relationship a phenomena arising from the travel and stay of strangers
(Ortsfremde) Provide the stay does not imply the establishment of a permanent resident.

\section{B. M. I.C.E Tourism}

Destinations M.I.C.E. is a convention tour, travel, incentive, and exhibition in the tourism industry. Here is the understanding of each component of M.I.C.E.

$\mathrm{M}=$ Meeting is an English term meaning meetings or hearings is a common practice that are organized by groups of people who join an association, or union.

I = Incentive, The incentive term, by the Indonesian government as stated in Law no. 9 of 1990 on tourism is defined as incentive travel. Furthermore, the incentive trip is determined that its business activities formulating incentive trips are a travel activity organized by a company for its employees and business partners in return for an award for their achievement in relation to the convention which discusses the development of the company's activities concerned.

$\mathrm{C}=$ Conference, the term conferences are translated by conferences in Indonesian that contain the same meaning, stating that conferences, congresses or conventions are an activity of meeting a group of people (statesmen, businessmen, etc.) to discuss issues related to common interests .

$\mathrm{E}=$ Exhibition. In relation to the tourism industry, the exhibits are included in the convention tour business.

\section{Review of Service Marketing Strategies}

Sucherly (2003: 219) states that the service marketing strategy includes two main strategies namely market strategy and marketing mix strategy.

1. Market Strategy.

The market strategy essentially determines the market segment to be served as a target market and market positioning. Determining the target market is very important considering the customer demands are not the same, so if different demands then how to serve it will be different. An important goal in selecting a target market is to find the most likely market which is relatively low level of competition. In positioning, the point is to place the marketing mix in order to achieve competitive advantage in the target market (Sucherly, 2003: 219).

2. Marketing Mix Strategy 
Marketing mix is basically a set of variables that the company can control to satisfy the target market in achieving its goals (Brown, 1991: 23). In the marketing of goods (tangible) known four tools are: product, price, place, and promotion or The Four Ps. The four tools are as The Traditional Marketing Mix. According to Kotler (2002: 18) marketing mix is a set of marketing tools that companies use to continuously achieve marketing objectives in the target market. McCarty (in Kotler, 2002: 18) classifies these tools into four broad groups called four P's in marketing: Product, Price, Place and Promotion. Certain marketing variables of each $\mathrm{P}$ are shown in Figure 1 below:

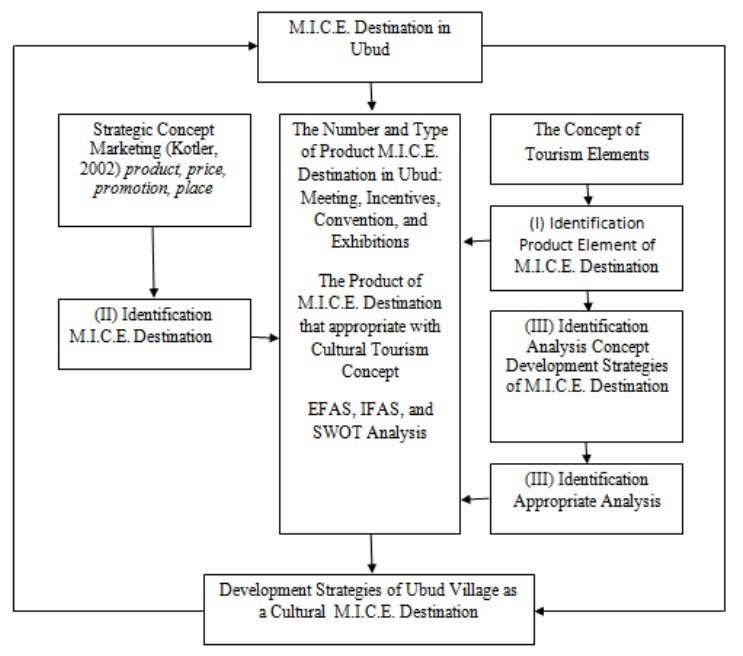

Figure 1 Research Design

\section{RESULTS DAN DISCUSSION}

\section{A. Identification Elements of M.I.C.E Tourism}

Bali is one of the MICE destinations in the Asia Pacific Region. Getz (1991: 45), in his book Festivals, Special Event and Tourism, gives an overview of the industry M.I.C.E. seen from the supply side. Getz says there are 7 (seven) elements in a destination M.I.C.E. The seven elements are (1) infrastructure, (2) accommodation, (3) transportation, (4) attraction, (5) catering, (6) retailer, (7) recreation or entertainment facilities. In Figure 1, what needs to be improved in M.I.C.E. destination. Here are seven elements of destination M.I.C.E. in the village of Ubud, such as:

\section{Infrastructure}

As one of the cultural tourism destinations, Ubud has a wealth of culture that must be preserved. However, in a highly developed era, Ubud is faced with challenges on infrastructure issues. The more famous Ubud in the eyes of global tourism cause the more tourists who will visit that destination. Along with that demand for lodging and entertainment also continues to grow in Ubud. However, Ubud is has a different location, vibes and always upholds the values of custom and culture where no investor builds nightclubs and entertainment in Ubud.

The problem of congestion is also one of the things underlined. Where the highway in Ubud is not as wide as other streets in Bali. This is coupled with the increasing number of tourists who bring private vehicles and even buses so that the required arrangement for Ubud is not abandoned by tourists and expected arrangement of Ubud on the concept of culture. Lack of parking pockets and the use of roads as parking lots and less visible signs on pedestrian lanes that are not friendly with pedestrians. These three things became the main factor as the root of the problems that occurred in Ubud. Solution to overcome traffic congestion problem that is provide adequate parking area, guarantee the comfort and security of visitor movement to the location of the tourist destination.

In addition to providing bike paths, and safe and comfortable pedestrian as an alternative transportation system in the region as well as implementing integrated intelligent transport information system in the movement volume control, and parking, it is no less important to build a community-based parking management system, the provision the "Shuttle Service" based public transport system that caters to visitors to the movement to major centers.

\section{Accomodation}

Gianyar is one of the tourist destinations on the island of Bali which has 390 hotels, with details of 19 star hotels and 367 non-star hotels. Of the 390 hotels, there are hotels with 25 rooms, with 2,042 rooms with a total of 2,624 beds. In 2016 the average length of stay in star hotels for 2.76 days and non-star hotels for 4.05 days. The hotel room occupancy rate in 2015 in Gianyar Regency is $57.22 \%$ for star hotels, and $36.96 \%$ for non-star hotels. Overall, the hotel occupancy rate in Gianyar is $47.09 \%$. The hotel room occupancy rate in 2016 increased when 
compared to 2015 of $44.67 \%$ for all types of hotels.

Hotel development growth rapidly in the Gianyar region especially in Ubud happening due to its location is in the village who has a natural atmosphere which is still beautiful and natural. It is also supported by the customs and cultures that are strongly attached to the lives of its inhabitants. Another influential factor is the stunning panorama of Ubud's nature, the terraced rice paddies, and the integrated natural environment to provide a tranquil atmosphere with a cool, fresh country air. The construction of a hotel that combines the modern and traditional Balinese style of Gianyar and supported by art galleries, artshop, and performing arts venues give its own color. Art galleries that exist and artshop provides various types of woodcraft art such as Barong and Garuda which is a replica of sacred objects. Likewise other artworks of wood crafts such as replicas of flora and fauna are formed based on the developing design.

Tabel 3

Data of Hotel Doing M.I.C.E. Activities in Ubud Village

\begin{tabular}{|c|c|c|c|c|}
\hline No & Name of The Hotel & $\begin{array}{l}\text { Guest } \\
\text { Room }\end{array}$ & Meetings Room & $\begin{array}{c}\text { Meeting } \\
\text { Size (sam) }\end{array}$ \\
\hline 1 & Sthala ubud. & 143 & 3 & 1687 \\
\hline 2 & Bijasa Agung Resort & 42 & 1 & 500 \\
\hline 3 & The ybud village and Spa & 60 & 1 & 500 \\
\hline 4 & Royal Pita Maha Resort and Spa & 24 & 5 & 491 \\
\hline 5 & Five Elements, Puri Ahimsa & 9 & 2 & 315 \\
\hline 6 & Bali Spirit Hotel and Spa & 25 & 1 & 300 \\
\hline 7 & Kamandaly Resort and Spa & 58 & 1 & 200 \\
\hline 8 & Sens Hotel and Spa & 97 & 2 & 162 \\
\hline 9 & Plataran ubud Hotel and Spa & 52 & 2 & 154 \\
\hline 10 & Wapa di Ume Resort & 18 & 1 & 140 \\
\hline 11 & Arma, Resort & 23 & 2 & 120 \\
\hline 12 & Komaneka at Bisma & 41 & 1 & 100 \\
\hline 13 & Taman Harum Cottages & 17 & 2 & 100 \\
\hline 14 & Maya Ubud Resort \& Spa & 108 & 1 & 96 \\
\hline 15 & The Viceroy Ubug, Bali & 25 & 1 & 80 \\
\hline 16 & Four Season Sayan & 60 & 1 & 50 \\
\hline 17 & сомо Una ubud & 46 & 1 & 36 \\
\hline 18 & Natura Villa ybud Resort and Spa & 14 & 1 & 10 \\
\hline 19 & Amandari & 30 & 1 & 50 \\
\hline 20 & Ananda cottage & 78 & 2 & 80 \\
\hline 21 & AniniRaka Resort \& Spa & 19 & 1 & 36 \\
\hline 22 & The Chedi Club at Tanah Gajah & 20 & 1 & 100 \\
\hline 23 & Eurama Villa ybud & 42 & 1 & 155 \\
\hline 24 & Komangka at Tangayuda & 20 & 1 & 120 \\
\hline 25 & The Rayggan Villa Resort \& Spa & 45 & 1 & 100 \\
\hline 26 & Pertivi Resort \& Spa & 76 & 1 & 80 \\
\hline 27 & Puri Garden Hotel & 27 & 1 & 70 \\
\hline 28 & Purisaron & 10 & 1 & 80 \\
\hline 29 & Puri Wulandari & 27 & 1 & 80 \\
\hline 30 & Santi Mandala Villa & 27 & 1 & 160 \\
\hline 31 & Suly Resort \& Spa & 16 & 1 & 100 \\
\hline 32 & Tiing Gading Bungalows & 10 & 1 & 60 \\
\hline \multirow[t]{2}{*}{33} & The Mansion Resort \& Spa & 80 & 1 & 160 \\
\hline & Total & 1309 & 45 & \\
\hline
\end{tabular}

Source: Research Result (2017)

3. Transportation
Ubud size is $42.38 \mathrm{~km} 2$ is located between the altitude of 75-325 $\mathrm{m}$ above sea level and length of road in Ubud in 2016 that is along $515,240 \mathrm{~km}$. The road along that if detailed by the type of surface there are 515,240 paved roads. If the road is detailed according to conditions, then along the $283,895 \mathrm{~km}$ with good conditions, $144,051 \mathrm{~km}$ with medium conditions, along $61,851 \mathrm{~km}$ of damaged condition, and 25,443 $\mathrm{km}$ with severe damage.

The number of mandatory test vehicles in 2016 in Gianyar regency is 11,991 vehicles, decreasing when compared to the year 2016 as many as 12,710 vehicles. The number of freight cars in 2016 was 11,663 vehicles, decreasing when compared with the number in 2015 which numbered 12,397 vehicles. There was a decrease of $5.92 \%$ in 2016 . The development of tourist transportation in Ubud Village from 2012-2016 can be seen in table 4. With the number of tourist transportation reaching 2565 transports, is a large amount for the provision of M.I.C.E transportation in the Village of Ubud.

Table 4

\section{Development of Tourists Transportation in} Ubud Village from year 2012-2016

\begin{tabular}{|l|c|}
\hline Year & $\begin{array}{l}\text { Amount of } \\
\text { Transportations }\end{array}$ \\
\hline 2016 & 2565 \\
\hline 2015 & 2621 \\
\hline 2014 & 2486 \\
\hline 2013 & 1399 \\
\hline 2012 & 955 \\
\hline
\end{tabular}

Source: Central Bureau Statistics of Gianyar

4. Atractions

Nature Tourism Attractions include: Mandala Wisata Wanara Wana, Ubud Campuhan Hills, Cultural Tourism Attractions include: Nyuh Kuning Village, Pura Taman Saraswati Ubud, Barong Ubud Dance with locations include: Sandi Swara Wantilan, Puri Saren Ubud, Pura Dalem Ubud, Legong Mahabrata Ubud Dance. Legong Dance Performance Venue in Ubud Bali: Puri Saren Ubud and Puri Agung Peliatan. Artificial Tourism Attractions include: Agung Rai Museum Of Art (ARMA), Neka Ubud Museum, 
Ubud Castle Painting Museum, Renaissance Blanco Museum, Rudana Museum and Art Gallery, Ubud Cooking Course, and Ubud Art Market

\section{Catering}

TripAdvisor sites in 2016 noted there are 516 restaurants located in Ubud area. This amount does not include the small and medium restaurant that is not recorded in the site. In the midst of intense competition and the proliferation of non-local restaurants, local cuisine with Balinese characteristics is very easy to find in Balinese cuisine in Ubud proved to provide an authentic cultural experience for both domestic and foreign tourists. This shows that the development of culinary tourism in a tourist destination can generate benefits for local communities and tourists visiting the destination (Nummedal and Hall, 2006; Okumuset al, 2007; Sims, 2009).

There are several healthy and vegetarian foods including Sari Organik, Café Pomengrate, The Kafe, and Bali Buda. With many restaurants in Ubud Village making food lovers form an event called Ubud Food Festival. Ubud Food Festival (UFF) in 2015 and successfully brought 6,500 culinary lovers from Indonesia and other countries to gather to celebrate the festivities and culinary wealth of Indonesia. The Ubud Food Festival lasts for three days and is filled by programs such as cooking demonstrations, workshops and masterclass, special events held at some Ubud culinary institutions, and culinary forums.

\section{Retail}

Traditional markets, are places of goods or services transactions between sellers and buyers, which have the following characteristics: a) selling goods / services of daily needs in retail; b) involving many small-scale retailers; c. The building and its market facilities are relatively simple; d) Ownership and management generally by local government. In Ubud Market there are 214 traders which 5 of them are gold traders.

\section{Recreation and Entertainment}

Recreational and entertainment tours examples, namely: Rafting Tour in Ayung Ubud River, Trekking Authentic Bali, and Silver Making Course.
Based on the identification of the elements above, there are several travel packages made by travel agents such as Pacto Convex and Pacific World especially for incentives program in Ubud Village, among others: Bali "Cooking Class \& Ubud Shopping, Bali Rise \& Shine in Bali and Bali "Ubud Arts \& Treasures", the programs of DMC Asia Plus include White Water Rafting, Eat and Pray Film location and styles such as Julia Robert and blessing ceremony in one village in Ubud Village, Monkey Forest, Dinner with Raja Ubud at Puri Saren and making silver.

\section{B. Identification of A Cultural M.I.C.E. Destination using Marketing Mix (4P)}

The marketing mix concept based on the market situation that concerns:

1. Product

The products and services offered must be clear and can be enjoyed as superior products and services such as: Monkey Forest, Puri Ubud, religious places (Gunung Lebah, Tirta Empul and Sebatu Temples), places of entertainment, attractions, recreational areas and more. In addition it can also be a tourist services such as spa, rafting, painting, batik making, and other entertainment.

Ubud Village as the destination of M.I.C.E. has not had a convention bureau, this is due to the characteristics of the tourists who come to Ubud and the needs required by the tourism industries component are different from other tourist destinations in Bali such as Badung regency and Denpasar municipality. During this time, the implementation activities of M.I.C.E. dominated by tourism incentives $(56.57 \%)$, exhibitions (31.72\%) and meetings (11.71\%). These incentives are mostly done by private or corporate companies, and then exhibition activities are conducted by individuals with dominant themed of painting and there are several exhibitions on photography where the painters who will conduct exhibitions will work with gallery owners, museums, hotels and restaurants so that they can display their work in the form of exhibition.

Tourism activities M.I.C.E. which relies on incentives and exhibitions on cultural activities such as cultural tourism attractions and 
exhibitions about paintings lead to the destination of Ubud Village as a cultural destination on M.I.C.E. in Bali. The number of foreign and domestic tourists who do tourism to the village of Ubud can be seen in the table as follows:

\section{Table 5}

Number of Tourists Conducting M.I.C.E Activities in Ubud Village from Year 2012-2016

\begin{tabular}{rrrrrrrr}
\hline \multirow{2}{*}{ Year } & \multicolumn{2}{c}{ Number of Tourist } & \multirow{2}{*}{ Total } & \multicolumn{4}{c}{ Number of MLI.C.E. Tourist } \\
\cline { 2 - 6 } \cline { 5 - 8 } & Foreign & Domestic & & Meeting & Insentif & Conrention & Exhibition \\
\hline 2012 & 22,771 & 30,981 & 53,751 & 6,294 & 30,407 & 0 & 17,050 \\
\hline 2013 & 38,096 & 21,085 & 59,180 & 6,930 & 33,478 & 0 & 18,772 \\
\hline 2014 & 54,685 & 48,065 & 102,750 & 12,032 & 58,126 & 0 & 32,592 \\
\hline 2015 & 55,748 & 15,338 & 71,086 & 8,324 & 40,213 & 0 & 22,548 \\
\hline 2016 & 102,015 & 28,851 & 130,865 & 15,324 & 74,031 & 0 & 41,310 \\
\hline
\end{tabular}

Source: Result of Research (2017)

Meetings is more dominated by corporations or companies that do M.I.C.E. activities which is combined with incentive activities during their stay in Ubud Village. In an effort to improve the services of convention services business, many policies have been done in an effort to increase tourist visit to Ubud Village (Tourism Office Gianyar, 2016). These efforts are: the construction of facilities and infrastructure services in M.I.C.E. to accommodate national and international convention activities, together with tourism associations, international tourism conventions and exchanges such as PATA, WTM, BTL, ITB Berlin, JATA, CITM, ATF, TATA, and Agency Development Promotion Indonesia (BPPI), as well as regional BPPI in Bali and surrounding areas, organizing international tourism events in Ubud Village, coaching the MICE training programs by conducting basic and advanced training courses, the participants consist of management / employees engaged in the field of services business M.I.C.E. and to supervise and control the service business of M.I.C.E. which violates the prevailing rules and regulations. The business infrastructure of convention services demanded by the market of M.I.C.E., according to Professional Congress Organizer / PCO, Daniels (2003), there are 3 important things that need attention of all parties, such as:

- Efficiency of land transportation system where public roads in Bali are still considered unsafe and not efficient so that travel time between attractions and places of convention can be disrupted.

- Health support system or medical support system where hospitals and clinics in Ubud Village still do not have international standards in assisting conventional tourist handling, as well as handling of emergency personnel should be improved.

- Telecommunication system. This system needs attention especially ease of use of mobile phone, local phone system and tele conferencing, wide band facility and wireless with Simoultaneous Interpreting System (SIS) still less qualified.

\section{Place}

This is related to the places that are addressed in a sequence and comfortable, a sense of security for tourists in coming to the tourist attraction.

3. Price

The price offered is a standard price where there is no need to bargain so that foreign tourists do not feel lied or treated unworthily, so feel satisfied.

4. Promotion

It needs to be promoted through various agencies or distribution channels throught communication channels such as: newspapers; personal selling; direct mail; flyers; radio; individual referral; television; E-mail; telephone; internet; posters, and others.

\section{Designing Product Development Strategies on M.I.C.E Destination in Ubud Village.}

Internal Assessment Analysis

1. Networking

Networking in Ubud Village is predominantly dominated by $43 \%$ of corporate, indicating that the activities or events are held involving the companies conducting meetings and incentives in Ubud Village. Private sector contributed $33 \%$ to networking on the development of M.I.C.E, $12 \%$ on foreign stakeholders, Bali provincial government by $7 \%$ and Gianyar regency government by $5 \%$. Networking goals increase investment, business, improve regional superior products and integrated promotion. Means to match the reason for the destination of M.I.C.E., in Ubud Village has a high growth rate, open jobs for 
many people, improve the welfare of the people and give impact to the people of Ubud Village.

\section{Management}

The functions of planning, organizing, directing, controlling and evaluation need to be considered, but there is still much to be improved especially the direction, control and evaluation. Ubud Village organizing role are the biggest one with $43 \%$, then planning an activity that plays an important role in M.I.C.E. management by $34 \%$, and controlling only $8 \%$, even evaluation has not been done, it shows that what is planned can not be realized yet, not even get direction and control, and evaluation.

The reasons for the ineffectiveness of the management implementation in Ubud Village are because of limited funds in planning and coordination of $45 \%, 25 \%$ infrastructure, $14 \%$ government support, $10 \%$ external stakeholder and human resources $5 \%$. The condition shows that Ubud Village needs to be more intense to invite stakeholders who are able to become investors especially for the event of M.I.C.E., improve infrastructure, and conduct study by inviting experts and academics to fix the village of Ubud in order to create the destination M.I.C.E.

\section{External Assesement Analysis}

1. Effective promotion and advertising Media campaigns conducted via the internet (web, blog, social media) by $63 \%$, newspapers by $21 \%$ and direct selling of $16 \%$ of exhibitions, billboards and cultural tourism. Respondents who were asked about the best media campaign and advertising, there is no promotion and the best advertising that needs to be maintained is brand name, so that tourists remembered the village of Ubud.

Ubud Village can attract foreign tourists effectively utilizing the Tourism Information Center (TIC), where tourists seek information on tourist attractions and travel services. TIC is linked to web, e-mail, even through magazines, bulletins, including newspapers or newspapers, as well as other television and media media, including hotels in Ubud.

2. Speed responds to market and technological change to the market can be done through the online system on information technology (IT) in the field of tourism known as e-tourism by $42 \%$, then do cooperation with investors by $23 \%$, response to the development trend of the destination M.I.C.E. which requires a quick response in order to take the opportunity to earn business M.I.C.E. 21\%, infrastructure improvement and $11 \%$ tourism improvement, $3 \%$ other than making brand image and brand name of Ubud Village. Branding village needs to be formulated to create an impression of its own uniqueness.

3. Corporate

In developing the M.I.C.E. need to work with companies that supported for Ubud Village. The cooperation is dominated by $45 \%$ of events, $30 \%$ continuous cooperation, $14 \%$ certain moment, and planning to conduct events by $11 \%$. In those cooperation needs to be $56 \%$ mutually beneficial activities, $12 \%$ joint venture, and there is a certain moment $32 \%$. This indicates that the cooperation has not yet demonstrated a win-win solution, but still short term is not yet co-partnership or sustainable cooperation.

\section{Supplier}

Supplier cooperation can be done with other suppliers, to maintain the quality of service and response to the tourists. Cooperation is happening spontaneously with $41 \%$ at a certain moment, $30 \%$ when there are events, and planning events of $29 \%$. Thus cooperation with business suppliers is made in a long-term service that is able to supply the needs of the tourists. Cooperation is done with mutual benefit with the reasons for the price to be cheaper, easier service, quickly respond to customers, brand image and others.

Cooperation is mutually beneficial if it can provide quality products in accordance with the needs and desires of both parties by 39\%, then cheap price with good product quality of $29 \%$, service that facilitate sustainability during the activities of M.I.C.E. lasts $25 \%$, while the brand image is not an important thing because the village of Ubud does not have the right brand image by $5 \%$. Thus, the village of Ubud has given the right reasons and has the right path in the cooperation with suppliers.

5. Availability of transport

Transportation availability in Ubud Village is the main reason for tourists to run the activities of M.I.C.E. to go to some places intended especially for tourists who are involved in the program of incentives by providing transportation in the form of private transport by $77 \%$; tourist transport owned by the tourism 
industry such as hotels and tour and travel companies by $18 \%$ and for the group provided medium bus that can enter the village of Ubud by $5 \%$. The use of private transport is carried out to provide local communities with the opportunity to earn an income from the tourism sector by providing travel services to tourists conducting the activities of M.I.C.E. in Ubud Village.

Frequently used transportation to the destination of M.I.C.E. which begins by picking up the MICE tourists, taking the spouse that takes the tour and escorting to the Airport using tourist transport owned by the hotel, tour and travel or private or private owned travel by $47 \%$, then using private transport that does not have a tourist transport license from the Department of Transportation of $32 \%$, to visit the relatively remote location of tourist dwellings or conduct comparative studies, then provided a bus of $14 \%$ and the use of transportation that allows travelers to travel alone by doing transport online in this case $7 \%$ cheaper reasons, and free time.

Indeed transportation options are the right of the tourists, thus local government should facilitate as expected of the tourists. Thus the availability of good transportation, convenient and adequate should be available easily during the event. Easy, convenient, safe and friendly access will give you satisfaction and will bring loyalty to come back to Ubud Village.

6. Customer satisfaction service

Customer service is central to the success of a business. Where respondents answer at tangible by $28 \%$; intangible and emphaty of $17 \%$; while assurance of $26 \%$ and responsiveness of $29 \%$. The condition that customer service is not satisfactory is the lack of information on services, infrastructure, congestion on the protocol streets of Ubud Village. To improve the service should be immediately held is a place and information board services easily viewed, infrastructure improvements as well as training to improve the quality of front liner services of tourism officers. This is all closely related to customer satisfaction, or the tourists and investors who invest in Ubud Village.

\section{Competitive Advantage Factors}

Competitive advantage is indispensable in the business world. Competitive advantage needed industry analysis include the presence of tourists, investors, and tourist attractions.

1. Industry analysis

In the industry analysis, the readiness to welcome M.I.C.E. business by $29 \%$ of tourism investors need, $28 \%$ need to have an alternative tourism destinations, and new tourist destinations and types for the market M.I.C.E. by $24 \%$, tourists, entertainment and other places by $14 \%$. The objective of a competitive strategy to find the position of Desa Ubud on the areas that focus on the business of M.I.C.E., and to diversify both the products and services that become the output of M.I.C.E.

2. External business environment

The external environment is a necessary environment for tourists to make tourism activities as expected and provide the maximum level of satisfaction. The existence of such a cultural place is $47 \%$; where the economy reaches $8 \%$, social place reaches $18 \%$, location for sports by $5 \%$, others concerning places of ceremonies and worship (temples that have an important role in the village of Ubud and surrounding areas) of $19 \%$ where many tourists do is to explore the cultural heritage, place of history, economic activity or shopping. In addition, other tourist activities are related to culture, old village and shopping.

\section{Market Situation}

The market deals with products, places, prices, promotions and more. Ubud Village as the destination of M.I.C.E. emphasizing the price of $29 \%, 36 \%$ products, promotion by $18 \%$, while the place of $17 \%$. It shows tourists see the work in which they travel, then see how much the price, and how the promotion.

4. The effectiveness of flexible resources

Ubud Village need to be utilized flexibly in their resources. One of their strength on natural resource effectiveness is $42.85 \%$, human resources $21.42 \%$, infrastructure $14.29 \%$, and methods and markets reached $7.14 \%$. This shows that nature in Ubud village needs to be explored optimally. Furthermore, human resources from various lines need to play a maximum role or be empowered to support Ubud as a destination of M.I.C.E., further explore its funding, method and market. Going forward for destinations M.I.C.E. required data about tourist information amounted to $35.29 \%$, precise time management of $29.41 \%$, moral of $23.52 \%$, and leadership of $11.76 \%$. 
This condition explains that tourism information becomes the main vehicle for tourists so it needs to provide enough information place. Furthermore, leaders who are able to provide examples and role models in the management of tour packages in a timely manner, and how to provide awareness and awareness to citizens to welcome tourists.

5. Competence Differences

The difference between Ubud Village and other villages will determine the future of Ubud Village as a destination of M.I.C.E. Ubud Village is a cultural village, tourism area, village geographical, as well as hilly areas that have distinctive characteristics that distinguish it from other villages. Competence needed by Ubud village to realize M.I.C.E. is the improvement of information and moral services. The ability of Ubud Village to identify the availability of resources and its carrying capacity will create advantages, both in terms of efficiency, quality, innovation, responsiveness to the tourists as well as providing a level of satisfaction for newcomers who invest in Ubud Village.

The difference with other villages with low cost creation allows Ubud Village to create value for the tourists and investors who finally get the maximum profit. Therefore the difference of competence lies not in its tangible factor but lies in the intangible factor that is able to distinguish with other tourism village.

\section{E. Critical Success Factor}

Ubud Village Competence is the availability of facilities such as hotel $41.66 \%$; exhibition space of $33.33 \%$; meeting room of $16.66 \%$, meeting room is still $0 \%$. This indicates that the hotel room already meets the availability, but the most urgent thing is the conference room at local, regional and international level. Similarly, space for meetings and open space that can accommodate the number of thousands of people was not yet available significantly. Based on the data made SWOT analysis, it can be seen in outline that becomes:

Table 6 SWOT of Ubud Village

\begin{tabular}{|l|l|}
\hline \multicolumn{1}{|c|}{ Opportunities } & \multicolumn{1}{c|}{ Threat } \\
\hline - Many festivals & - No specific village branding \\
- Many exhibits & yet \\
- Plenty of open space for & - Foreign products that flooded \\
events & the village of Ubud \\
- Many souvenir shopping & - Less technological changes are \\
places available & anticipated \\
- Lots of cultural and & - Not many national and \\
\hline
\end{tabular}

\begin{tabular}{|c|c|}
\hline $\begin{array}{l}\text { historical appeal } \\
\text { - Many religious attractions } \\
\text { - Many culinary places } \\
\text { - Different geographical } \\
\text { location } \\
\text { - Number of investor } \\
\text { cooperation offer } \\
\text { - Events happen repeatedly }\end{array}$ & $\begin{array}{l}\text { international events } \\
\text { - Historical, cultural and } \\
\text { religious tours } \\
\text { - Many big events at the } \\
\text { attraction of Ubud Village } \\
\text { - Consumer culture is } \\
\text { increasingly widespread } \\
\text { - Productive culture is less } \\
\text { developed } \\
\text { - Many congestion and accident } \\
\text { prone } \\
\text { - Security is still not guaranteed }\end{array}$ \\
\hline Strength & Weaknesses \\
\hline $\begin{array}{l}\text { - Interesting geographical } \\
\text { location } \\
\text { - Many private networking } \\
\text { and abroad } \\
\text { - Many planning activities } \\
\text { linked tourism } \\
\text { - Support from the village } \\
\text { government } \\
\text { - Promotion and advertising } \\
\text { via the internet } \\
\text { - Quickly respond to the } \\
\text { market with investors, } \\
\text { customers } \\
\text { - Improved sustainable village } \\
\text { governance } \\
\text { - Cooperation in partnership } \\
\text { - Rural transportation is } \\
\text { available } \\
\text { - Settlement in infrastructure } \\
\text { and village face } \\
\text { - Many places of cultural and } \\
\text { economic activities } \\
\text { - Many products can be } \\
\text { offered } \\
\text { - Unspoiled natural panorama } \\
\text { - There are cultural } \\
\text { differences with other villages } \\
\text { - Adequacy of the hotel }\end{array}$ & $\begin{array}{l}\text { - Culture places are not fully } \\
\text { organized } \\
\text { - The place of performances and } \\
\text { the economy is less regular } \\
\text { - There are similar events over } \\
\text { and over again } \\
\text { - Hotel promotions less } \\
\text { integrated with tours } \\
\text { - Nature tourism has not been } \\
\text { explored to the fullest } \\
\text { - Event less integrated } \\
\text { - Culinary tour less organized } \\
\text { - Event place has not been } \\
\text { maximized } \\
\text { - Not yet involving all the } \\
\text { potential of Ubud Village } \\
\text { - The event has not had a real } \\
\text { impact on people's welfare } \\
\text { - There is a TIC (Tourism } \\
\text { Information Center) but have not } \\
\text { been able to cooperate } \\
\text { - Many villagers are still not } \\
\text { aware of tourism } \\
\text { - Still think the profit and loss } \\
\text { has not yet thought long-term } \\
\text { benefits }\end{array}$ \\
\hline
\end{tabular}

Source: Result of Research 2017

SWOT analysis can be seen from the internal factors aimed at the strength that is customer needs that can or have been met. While weakness associated with customer needs that need to be minimized. In addition, external factors are shown opportunities that can be developed in the village of Ubud, and threats are minimized. In developing the M.I.C.E. a strategy developed when $\mathrm{S}>\mathrm{W}$ and $\mathrm{O}>\mathrm{T}$ are used expansion strategies and when $\mathrm{S}<\mathrm{W}$ and $\mathrm{O}$ $<\mathrm{T}$ are used consolidation strategies. The identification results can be combined with S-O, S-T, W-O, and W-T, as shown in Table 7 of SWOT Matrix.

Tabel 7 Matrix SWOT

\begin{tabular}{|c|c|c|}
\hline \multirow[t]{2}{*}{ Strategy } & \multicolumn{2}{|c|}{ E X T E R N A L } \\
\hline & OPPORTUNITY & THREATS \\
\hline & S-O & S-T \\
\hline & - Geographical location & - Place of cultural, \\
\hline
\end{tabular}




\begin{tabular}{|c|c|c|c|}
\hline $\begin{array}{l}\mathbf{N} \\
\mathbf{T} \\
\mathbf{E} \\
\mathbf{R} \\
\mathbf{N}\end{array}$ & $\begin{array}{l}\mathbf{S} \\
\mathbf{T} \\
\mathbf{R} \\
\mathbf{E} \\
\mathbf{N} \\
\mathbf{G} \\
\mathbf{H}\end{array}$ & $\begin{array}{l}\text { - Number of events } \\
\text { available } \\
\text { - The number of culinary } \\
\text { attractions } \\
\text { - The number of places } \\
\text { where the event is used } \\
\text { maximally } \\
\text { - Can hold many investors }\end{array}$ & $\begin{array}{l}\text { economic activity less } \\
\text { organized } \\
\text { - Local or locally scaled } \\
\text { events are held over and } \\
\text { over again, less } \\
\text { promotive tends to be } \\
\text { dispromotive. } \\
\text { - historical (cultural) and } \\
\text { spiritual attractions, not } \\
\text { maintained, left as is } \\
\text { - No specific brand name }\end{array}$ \\
\hline $\mathbf{A}$ & & W-O & W-T \\
\hline $\mathbf{L}$ & $\begin{array}{c}\mathbf{W} \\
\mathbf{E} \\
\mathbf{A} \\
\mathbf{K} \\
\mathbf{N} \\
\mathbf{E} \\
\mathbf{S} \\
\mathbf{E} \\
\mathbf{S}\end{array}$ & $\begin{array}{l}\text { - Event less integrated } \\
\text { - Lack of investor } \\
\text { (funding) } \\
\text { - Lack of tourism } \\
\text { information center } \\
\text { - Many access roads } \\
\text { jammed or infrastructure } \\
\text { has not been explored to } \\
\text { the fullest } \\
\text { - Lack of residents } \\
\text { entertainment } \\
\text { - The lack of superior } \\
\text { products } \\
\text { - Lack of networking } \\
\text { - Lack of management } \\
\text { ability } \\
\text { - Promotion and } \\
\text { advertising limited to } \\
\text { local } \\
\text { - Limited quality of } \\
\text { service } \\
\text { - Events of national and } \\
\text { international scale have } \\
\text { not been explored }\end{array}$ & $\begin{array}{l}\text { - The entry of foreign } \\
\text { products, as well as new } \\
\text { technologies } \\
\text { - Technology changes - } \\
\text { Large-scale Events } \\
\text { withdrawn from Badung } \\
\text { regency } \\
\text { - Tourism history and } \\
\text { religion lost to other } \\
\text { villages }\end{array}$ \\
\hline
\end{tabular}

Source: Result of Research 2017

The result can be drawn a conclusion that in the village of Ubud is still in category $\mathrm{S}<\mathrm{W}$ and $\mathrm{O} \geq \mathrm{T}$ thus still must be done internal consolidation; but seeing $\mathrm{O} \geq \mathrm{T}$ still has potential for further development. More detailed analysis with included scores and weights for the indicators analyzed.

\section{F. Analysis}

\section{Internal Analysis}

Based on result of reseach, each variables as follows:

Table 8 Average Score for Internal Variabel

\begin{tabular}{clc} 
No & Key Success Factors & Score \\
\hline 1 & Location of Exhibitions & 0,3 \\
\hline 2 & Accomodation or Hotel & 0,4 \\
\hline 3 & Transportation & 0,3 \\
\hline 4 & $\begin{array}{l}\text { Exhibtions competency for } \\
\text { stakeholders }\end{array}$ & 0,1 \\
\hline
\end{tabular}

\begin{tabular}{clc}
\hline 5 & Stakeholders & 0,3 \\
\hline 6 & Place of interest & 0,1 \\
\hline 7 & Post convention tour & 0,3 \\
\hline 8 & Convention organisation & 0 \\
\hline Amount & 1,8 \\
\hline
\end{tabular}

\section{External Analiysis}

Analysis of external variables includes globalization, tourism potential, industrial structure, economy, technology, and government. The value in Table 9, the value of internal variables of 0.5 (medium conditions) and external variables 1.1 (high chance conditions), external variables as follows see Table 9 below:

\section{Tabel 9 Nilai Rata-Rata Variabel Internal}

\begin{tabular}{clc} 
No & Key Success Factor & Score \\
\hline 1 & Globalisation & 0,1 \\
\hline 2 & Tourism Potential & 0,6 \\
\hline 3 & Industrial Structure & 0,4 \\
\hline 4 & Economy & 0,3 \\
\hline 5 & Technology & 0,1 \\
\hline 6 & Government & 0,5 \\
\hline & Total & 1,1
\end{tabular}

Based on Table 8 and 9, can be defined that internal variable grade at 1,8 (high opportunity condition) dan external variabel at 1,1 (high opportunity condition).

\section{G. Strategy}

Based on the positioning of Desa Ubud as the destination of M.I.C.E. lies in the condition of internal variables of 1.8 (high probability conditions) and external variables 1.1 (high opportunity conditions) then the strategy choices appear in Table 10, the following:

Table 10. Development Strategy of Ubud Village 


\begin{tabular}{|c|c|c|c|c|}
\hline & \multicolumn{3}{|c|}{ EXTERNAL CONDITION } \\
\hline & & HIGH & MEDIUM & LOW \\
\hline \multirow{3}{*}{$\begin{array}{c}\text { INTER } \\
\text { NAL } \\
\text { CONDI } \\
\text { TION }\end{array}$} & HIGH & $\begin{array}{ll}\text { - } & \text { Dominant } \\
\text { Growth } \\
\text { - } \\
\text { Invesimum } \\
\text { Investment }\end{array}$ & $\begin{array}{ll}\text { - Selective } \\
\text { Growth } \\
\text { - Agressive } \\
\text { Investment } \\
\text { - Maintain } \\
\text { Position } \\
\text { Elsewhere }\end{array}$ & $\begin{array}{l}\text { - Maintain } \\
\text { Position } \\
\text { - Looking for } \\
\text { cash in } \\
\text { - Potluck } \\
\text { Investment }\end{array}$ \\
\hline & MEDIUM & $\begin{array}{l}\text { - Fix Weakness } \\
\text { - Build Excellence }\end{array}$ & $\begin{array}{l}\text { - Growing by } \\
\text { Market } \\
\text { Segment } \\
\text { - Specialization } \\
\text { - Selective } \\
\text { Investment } \\
\end{array}$ & $\begin{array}{l}\text { - Pruning } \\
\text { - Minimum } \\
\text { Investment } \\
\text { - Ready to } \\
\text { Invest }\end{array}$ \\
\hline & LOW & $\begin{array}{l}\text { - Specializes in } \\
\text { Finding a Niche } \\
\text { Market } \\
\text { - Consider the } \\
\text { Acquisition }\end{array}$ & $\begin{array}{l}\text { - Specializes in } \\
\text { Finding a } \\
\text { Niche Market }\end{array}$ & $\begin{array}{l}\text { - Follow The } \\
\text { Market Leader } \\
\text { - Invested } \\
\text { Disnupt The } \\
\text { Source of The } \\
\text { Competitor's } \\
\text { Cash Flow }\end{array}$ \\
\hline
\end{tabular}

Based on SWOT analysis, matrix strategies for developing Ubud as M.I.C.E destination as follows:.

Table 11 Development Strategies Ubud Village as M.I.C.E Destination

\begin{tabular}{|c|c|c|c|}
\hline $\begin{array}{c}\text { Strate } \\
\text { gy }\end{array}$ & Programs & Action Plan & $\begin{array}{c}\text { Informati } \\
\text { on }\end{array}$ \\
\hline \multirow[t]{3}{*}{ Growth } & $\begin{array}{l}\text { Create more } \\
\text { varied and } \\
\text { unique events }\end{array}$ & $\begin{array}{l}\text { Involved } \\
\text { Stakeholder in } \\
\text { tourism industry to } \\
\text { create the program } \\
\text { related M.I.C.E. }\end{array}$ & $\begin{array}{l}\text { Still less } \\
\text { varied and } \\
\text { involvement }\end{array}$ \\
\hline & $\begin{array}{l}\text { Improve } \\
\text { national and } \\
\text { international } \\
\text { scale events } \\
\end{array}$ & $\begin{array}{l}\text { Cooperation with } \\
\text { national and } \\
\text { international events } \\
\text { organiser }\end{array}$ & Coordination \\
\hline & $\begin{array}{l}\text { Organize } \\
\text { cultural, } \\
\text { economical and } \\
\text { spiritual } \\
\text { activities }\end{array}$ & $\begin{array}{l}\text { Integration into one } \\
\text { tour package }\end{array}$ & Not Available \\
\hline \multirow[t]{2}{*}{$\begin{array}{l}\text { Dominan } \\
\text { ce }\end{array}$} & $\begin{array}{l}\text { Strengthen } \\
\text { Ubud Village } \\
\text { branding as a } \\
\text { cultural village }\end{array}$ & $\begin{array}{l}\text { Promote cultural, } \\
\text { economical and } \\
\text { culinary potency }\end{array}$ & Coordination \\
\hline & $\begin{array}{l}\text { Improve } \\
\text { networking with } \\
\text { Stakeholder and } \\
\text { TIC }\end{array}$ & $\begin{array}{l}\text { Cooperation with } \\
\text { tourism stakeholders } \\
\text { within and outside } \\
\text { of the country }\end{array}$ & Coordination \\
\hline \multirow[t]{2}{*}{$\begin{array}{l}\text { Maximu } \\
\mathrm{m} \\
\text { Investme } \\
\mathrm{nt}\end{array}$} & $\begin{array}{l}\text { Engaged with } \\
\text { investor who } \\
\text { care and } \\
\text { maintain culture } \\
\text { in Ubud }\end{array}$ & $\begin{array}{l}\text { Cooperation with a } \\
\text { good quality } \\
\text { investor inside or } \\
\text { outside the country }\end{array}$ & $\begin{array}{l}\text { Still less } \\
\text { engaged with } \\
\text { investor to } \\
\text { maximize the } \\
\text { investment }\end{array}$ \\
\hline & $\begin{array}{l}\text { Increased } \\
\text { budget } \\
\text { allocation for } \\
\text { infrastructure } \\
\text { and tourism } \\
\text { activities in } \\
\text { MICE }\end{array}$ & $\begin{array}{l}\text { Proposal through } \\
\text { government fund or } \\
\text { donation or funded } \\
\text { by private } \\
\text { organisation }\end{array}$ & Coordination \\
\hline
\end{tabular}

The SWOT results concluded that Ubud Village is still $\mathrm{S}>\mathrm{W}$ and $\mathrm{O} \geq \mathrm{T}$ thus requiring internal consolidation; but seeing $\mathrm{O} \geq \mathrm{T}$ has potential for development Development strategy using grand strategy as follows: a) Growth, b) Domination, and c)
Maximum Investment, in detail can be seen in Table 11 Strategy Matrix.

1. The basic weakness lies in the absence of adequate convention space in Ubud Village which makes it difficult for MICE tourism to develop, as well as the lack of coordination between tourism information center which still has interests and runs independently, doesn't have branding yet, still requires investors who care with Balinese customs particularly in cultural and business development, try to maximize promotion, many access roads are jammed or infrastructure has not been explored optimally.

2. The strategy can be explained in the market penetration strategy; strategy (networking), as well as ongoing cooperation with private sector and domestic and foreign investors, the goal is to make more funds coming in to create accelerated development. The competitive advantage factor of Ubud Village as a destination of M.I.C.E. can be done through the development of the destination support sector of M.I.C.E. such as: a) investment, b) licensing, c) industry, d) communications, e) trade and services, f) health and safety, and g) arts or culture. 1. In the field of investment focus on providing facilities for the implementation of destination M.I.C.E. by highlighting Bali's strong traditional cultures in Ubud Village. Investment opportunities from abroad are built through regulations and incentives, need to be fully utilized. 2. Licensing is associated with the implementation of the activities of M.I.C.E., both the main activities of the destination M.I.C.E. as well as supporting facilities, such as: accommodation, conventions, exhibitions, services, trade and others.

3. The industrial sector has two roles to support the development of tourism, namely: 1) the number of industries is potential in organizing convention and exhibition activities, conferences, meetings, exhibitions; 2) small industry can not be separated with tourism activities, or its contribution is associated with the production of handicrafts, food and culinary. 3. Transportation relating to urban tourism activities, emphasis on destination activities M.I.C.E. This need to facilitate the connection between the arrival gate to the accommodation facility or convention, also connects other tourist attractions such as historical artifacts and cultural attractions as well as to other tourist villages in Indonesia and abroad. 4. Trade and services closely related to tourism activities. Shopping activities can not be separated from tourism activities especially M.I.C.E. destinations, so supermarkets and markets, traditional and specific markets are desperately needed as an 
important place that needs to get attention in the development of Ubud Village as the destination destination of M.I.C.E. 5. Health and safety are the demands of foreign tourists. Health insurance is not just a treatment facility, but health insurance, hygiene such as food and beverages and other items consumed. The sense of security for tourists is instrumental in maintaining and increasing tourist numbers. Especially for travelers associated with M.I.C.E are generally executives who are accustomed to get privacy and security.

4. Arts and culture become very important for tourists. Artistic elements can not be separated from urban tourism activities, for the activities of M.I.C.E. Art is required to be presented in new packaging in a certain format. Artistry that is presented in a specific and neat and culturally will leave a deep impression, including rituals, religions, ancient villages and unique specific places. Key factors of critical success, implementation of M.I.C.E. depending on the hotel room, meeting room; an incentive room; conference room; and exhibition hall and supporting facilities. In addition, the demands of professional human resources to manage and organize the convention. The implementation of the destination of M.I.C.E. tailored demands of Global Perspective Tourism, depending on component owner, supplier, professional convention organizer, professional exhibition organizer, and others.

\section{CONCLUSION}

1. The ability of the village strategy needed to the village of M.I.C.E., based on SWOT analysis is in the category $\mathrm{S}>\mathrm{W}$ and $\mathrm{O}>\mathrm{T}$ thus need to do internal consolidation; see $\mathrm{O}>\mathrm{T}$ a lot of potential that can be further developed. The grand strategy analysis of Ubud Village: a) Growth; b) Domination; and c) Maximum Investment where the need for convention space must be fulfilled in order to implement the activities of M.I.C.E. in Ubud Village

2. Excellence Factor Competing as a destination M.I.C.E. carried out through supporting sectors such as: a) cultured investment; b) licensing; c) industry; d) communications; e) trade and services; f) health and safety; and g) art or culture.

3. Key factors Critical success depends on the availability of physical facilities, such as hotels, meeting rooms, incentive rooms, conference rooms, and exhibition space and supporting facilities as demand demands. In addition to the demands of professional human resources to manage and organize conventions.

4. To realize the village of Ubud as a destination M.I.C.E., there are two important things that must be implemented: a) integrate the event M.I.C.E. integrated with the involvement of public service, private sector and people; $b$ ) daring to attract national and international events conducted in Ubud Village; and c) events in all sectors are mapped out in detail over a period of time and promoted to all corners of the globe and should the event be held to have the greatest effect on the welfare of the people of Ubud Village and its surroundings.

\section{SUGGESTION}

1. Grand strategy as a destination M.I.C.E., which is to improve the weaknesses and build the benefits of Ubud Village, need to be followed up, in the program and action plan.

2. Competitive advantage factors can be realized through improvements supporting the development of tourism support sector M.I.C.E. such as: a) investment; b) licensing; c) industry; d) communications; e) trade and services; f) health and safety; and g) art or culture.

3. Critical success factors require building facilities or suitable convention space for the venue of M.I.C.E.

4. To realize Ubud as a destination M.I.C.E. realized through integrated events, should be national and international and affect the welfare of Ubud Village community, and promoted worldwide

\section{BIBLIOGRAPHY}

Cooper, Chris, Jhon Flecher, David Gilbert and StephenWainhill. 1993. Tourism Principle and Practice. London : Pitman Publishing.

Kotler, P. 2002. Manajemen Pemasaran. Jilid I Edisi Bahasa Indonesia. Jakarta: Pearson Education Asia Ptc. Ltd. dan PT Prenhallindo.

Kotler, P. Bowen, J. Makens. 2002. Pemasaran Perhotelan dan Kepariwisataan. Edisi Bahasa Indonesia, edisi kedua. Jakarta: Pearson Education Asia Pte. Ltd. dan PT Prenhallindo.

Sucherly. 2003. Strategi Pemasaran Jasa dalam Meningkatkan Keunggulan Bersaing. Dalam 
Strategi Baru Manajemen Pemasaran. Editor Usmara, A. Jogjakarta: Amara Book.

http://venuemagz.com/September-2012/seminar-

wisata-spiritual-go-to-bali-before-i- die.html diunggah pada tanggal 24 November 2015.

http://ravel.kompas.com/read/2012/01/06/16000175/

Wisata.Spiritual.di.Bali.Belum.

Digarap.Maksimal. Diunggah tanggal 24

Nopember 2015.

2008, Buku Direktori

Usaha Pariwisata Desa Ubud Tahun 2008, Dinas Pariwisata, Desa Ubud, Ubud.

------------. 2006 , Buku I, II dan III

Cetak Biru Pemasaran Pariwisata Nasional, Departemen, Pariwisata, Jakarta. 